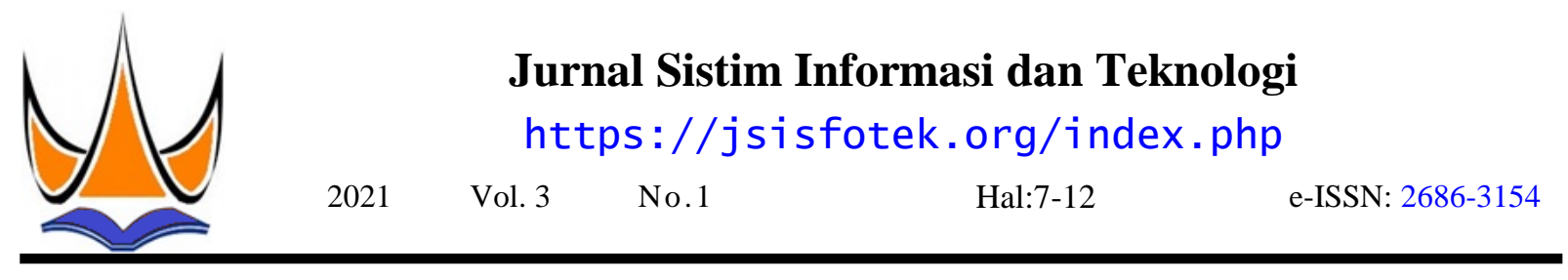

\title{
Sistem Pendukung Keputusan dalam Identifikasi Motif Songket Silungkang Menggunakan Metode AHP
}

\author{
Putri Humairoh $^{1 凶}$, Gunadi Widi Nurcahyo ${ }^{2}$ \\ ${ }^{1,2}$ Universitas Putra Indonesia YPTK Padang \\ putrihumairoh55@gmai1.com
}

\begin{abstract}
Songket Silungkang is a traditional weaving product made with special tools and is the creation of weavers from the Silungkang area. Songket has various types of motifs that are currently popular in Indonesia. So that it becomes a consideration for songket enthusiasts to get information about the songket motif. In this case, a proper analysis is needed to speed up the identification process in determining the Silungkang songket motif. Therefore we need a model that can describe all computerized systems that support the decision-making process. The decision support system using the Analytical Hierarchy Process method assesses each motive with the criteria and changes in the weight value. The criteria used in identifying Silungkang songket motifs are the type of material, the shape of the motif and the color of the motif. This study produces a matrix of yield weight, with the highest value of $90.0 \%$. So that from the final results of the calculation, it can be identified that the most popular songket Silungkang motif at the INJ Songket Store is the pucuak rabuang motif. This is useful for facilitating decision making related to the identification of Silungkang songket motive in the future.
\end{abstract}

Keywords: Identification, Decision Support System, AHP, Songket Motive, Silungkang.

\begin{abstract}
Abstrak
Songket Silungkang merupakan produk tenun tradisional yang dibuat dengan alat khusus dan merupakan kreasi penenun dari daerah Silungkang.Songket memiliki berbagai macam jenis motif yang saat ini sedang populer di Indonesia.Sehingga menjadi pertimbangan bagi para peminat songket untuk mendapatkan informasi tentang motif songket. Dalam hal ini diperlukan analisa yang tepat untuk mempercepat proses identifikasi dalam menentukan motif songket Silungkang. Oleh karena itu dibutuhkan sebuah model yang dapat menggambarkan seluruh sistem komputerisasi yang mendukung dalam proses pengambilan keputusan. Sistem pendukung keputusan dengan menggunakan Metode Analytical Hierarchy Process ini melakukan penilaian pada setiap motif dengan kriteria dan perubahan nilai bobot.Kriteria yang digunakan dalam identifikasi motif songket Silungkang yaitu jenis bahan, bentuk motif dan warna motif. Penelitian ini menghasilkan matriks bobot hasil, dengan memperoleh nilai tertinggi yaitu 90,0\%. Sehingga dari hasil akhir perhitungan maka dapat diidentifikasi motif songket Silungkang yang terpopuler di Toko Songket INJ adalah motif pucuak rabuang. Hal ini berguna untuk memudahkan pengambilan keputusan yang terkait dengan identifikasi motif songket Silungkang dimasa yang akan datang.
\end{abstract}

Kata kunci: Identifikasi, Sistem Pendukung Keputusan, AHP, Motif Songket, Silungkang.

(ㄷ) 2021JSisfotek

\section{Pendahuluan}

Indonesia merupakan negara yang kaya akan budaya, salah satunya adalah hasil kerajinan kain songket. Kain songket terbuat dari kain dengan berbahan dasar benang (kapas, sutra, dan serat). Kemudian kain ditenun sehingga menghasilkan gambar dengan bermacam-macam motif. Songket dijadikan warisan turun-temurun dari nenek moyang terdahulu. Menenun saat itu adalah pekerjaan perempuan yang sekaligus melambangkan status sosial. Semakin banyak kain songket yang dihasilkan maka semakin tinggi status sosial masyarakat. Warisan budaya ini hanya dimiliki beberapa kelompok masyarakat saja di Indonesia, salah satunya di Sumatera Barat yaitu nagari Silungkang.

Silungkang dinyatakan sebagai nagari awal kerajinan Toko Songket INJ merupakan salah satu toko yang tenun di Sumatera Barat. Salah satu karya tenun yang berada di Kecamatan Silungkang.Ciri khas songket terkenal adalah karya tenun songket Silungkang. Silungkang ini terletak pada corak dan motifnya.Motif Menenunsangat sederhana dilakukan menggunakan alat yang dihasilkan berbentuk pucuak rabuang, itiak khusus tenun bukan mesin (palanta). Songket pulang patang, burung merak dan lainnya.Pada detail Silungkang merupakan produkindustritradisional yang motif juga memiliki ciri khas yaitu benang emas, perak, sudah terkenal dan berasal dari Kota Sawahlunto. Dahulunya, songket Silungkang ini digunakan bagi masyarakat Minang sebagai simbol status sosial seseorang [1]. Motif-motif yang ada pada sehelai kain gket memiliki nilai-nilai estetika yang tinggi.Teknik pengerjaannya begitu sulit untuk kombinasi berbagai motif, sehingga membutuhkan proses penciptaan dan pembuatan yang lama. Sekarang motif yang cenbang cenderung berbentuk praktis.Beberapa pengrajin dan hanya dijadikan sebagai cenderamata. Ada pemesan pakaian yang menyerahkan sepenuhnya kepada penenun soal motif apa yang akan digunakan pada perlengkapan pakaian adat. 
tembaga dan tidak menutupi seluruh permukaan kain. Penerapan Metode AHP dalam Pemilihan Bibit Jagung Semuanya dipadu dengan kombinasi warna yang Unggul yang bertujuan untuk menganalisis kriteria menarik.Pada penelitian ini akan dilakukan salah satu prioritas tertinggi dari bibit jagung seperti kriteria cara yang efektif dalam menyeleksi identifikasi motif ketahanan hama, ukuran buah dan waktu panen [8]. F. songket Silungkang yaitu dengan menerapkan SPK Leccese, dkk (2020) meneliti tentang Penilaian kualitas untuk mendapatkan hasil yang tepat. Diperlukan pencahayaan di ruang pendidikan yang menghasilkan ketelitian yang tinggi dalam menyeleksi satu per satu korespondensi antara metode yang diusulkan dengan motif yang tersedia pada Toko Songket INJ. Dengan survey subjektif [9]. Rosiska dan Harman (2019) menggunakan metode AHP diharapkan dapat meneliti tentang Metode Analitical Hierarchy Process membantu pengrajin dalam memenuhi permintaan dari (AHP) Dalam Pemilihan Umum Presiden Indonesia pelanggan dan mengenalkan motif- motif apa saja yang 2019 menghasilkan nilai 85,9\% untuk nomor urut 01 tersedia.

dan nilai $14,1 \%$ untuk nomor urut 02 [10]. Vojtek dan Vojtekova (2019) meneliti tentang Penerapan Metode

Identifikasi merupakan kegiatan mengumpulkan atau mencari sebuah data serta informasi dari kebutuhan di lapangan. Identifikasi dapat dikaitkan dengan suatu pengenalan sebuah objek yang akan diteliti. Motif adalah corak atau gambar yang didesain dari bagianbagian bentuk, garis maupun elemen yang membuat benda tersebut terlihat menarik.Saat ini teknologi yang diciptakan oleh manusia dapat meningkatkan kemampuan dalam menjalankan pekerjaannya. Seseorang akan banyak dihadapkan pada pembuatan keputusan seperti keputusan terhadap perencanaan, pelaksanaan, pengawasan, dan penilaian.

AHP kerentanan kondisi banjir yang menghasilkan $33,1 \%$ kerentanan tinggi terhadap banjir dan 70,9\% kerentanan sangat tinggi terhadap kejadian banjir [11]. Hasni, dkk (2019) meneliti tentang penetapan penerimaan besaranpembiayaan pada KPN Syariah AlIkhlas IAIN Batusangkar menghasilakan prioritas skor tertinggi yaitu 95,3\% [12]. Prasetyo, dkk (2019) meneliti tentang Analisis Kriteria utama berat badan ideal untuk penanganan jembatan menggunakan Metode AHP dan Promethee II menghasilkan prioritas utama yaitu 8 rusak parah, dan berat tertinggi adalah jembatan Klaling- Tanjung 0,5 [13]. Asti dan Ekantari Dalam Sistem Pendukung Keputusan (SPK) terdapat (2020) meneliti tentang Penerapan Produk Coklat berbagai metode yang dapat digunakan seperti Hitam dengan Metode AHP menghasilkan produk pemilihan, identifikasi, perbandingan, dan coklat hitam yang diperkaya dengan S.platensis bobot perangkingan. Perusahaan memanfaatkan SPK dalam prioritas 55,8\% [14]. Siswanti, dkk (2020) meneliti pemecahan suatu masalah berdasarkan analisis untuk tentang Penentuan Kenaikan Jabatan dengan Metode menentukan alternatif secara cepat, tepat, dan akurat. AHP dan Metode TOPSIS menghasilkan prioritas yang SPK merupakan sebuah sisteminteraktif yang diberikan kepada guru terbaik dengan nilai 0,7238 [15]. mendukung analisis data dan model keputusan. SPK Darko, dkk (2019) meneliti sebuah metode AHP juga digunakan pada orientasi di masa akan datang dengan digunakan peneliti dalam penerapan AHP untuk waktu yang tidak terjadwal dalam situasi konstruksi.Penelitian ini menunjukkan bahwa semiterstruktur maupun tidak terstruktur [2]. SPK manajemen risiko dan konstruksi berkelanjutan adalah didesain dan diimplementasikan dengan mudah oleh area aplikasi AHP paling populer.Selain itu, AHP orang yang memiliki kemampuan dasar pengoperasian menggunakan ukuran sampel yang kecil dan tingkat komputer [3]. Analytic Hierarchy Process (AHP) konsistensi yang tinggi. Pada masa depan diperlukan didasarkan pada sebuah teori yang mempelajari suatu untuk membandingkan dan membedakan antara AHP pengukuran melalui perbandingan berpasangan [4]. dan metode pengambilan keputusan multikriteria Penilaian hasil AHP tergantung pada penilaian dari lainnya [16].

seorang peneliti untuk menemukan prioritas. Perhitungan dalam perbandingan dilakukan menggunakan skala penilaian untuk menghitung berapa banyak suatu elemen terhadap elemen lain berdasarkan atribut yang diberikan [5].

Metode AHP merupakan metodeuntuk menghadapi 2. Metodologi Penelitian persoalan kompleks yang dapat dipercepat dalam proses pengambilan keputusan. Metode ini digunakan sebagai metode dalam penguraian masalah multi kriteria atau multi faktor menjadi suatu hirarki [6]. Tujuan dan keputusan dalam metode AHP adalah tingkat teratas pada hirarki.Tingkat dibawahnya adalah kriteria, jika masih bisa dipecah maka tingkat selanjutnya yaitu subkriteria sampai menemukan keputusan akhir yang disebut alternatif [7].

Penelitian terdahulu menggunakan metode AHP

Dengan menggunakan metode AHP diharapkan dapat membantu pengelola dalam identifikasi motif songket Silungkang yang tersedia secara tepat waktu dan hasil telaah yang lebih akurat.

Metode penelitian merupakan proses atau cara ilmiah agar mendapatkan suatu data yang akan digunakan untuk penelitian. Suatu penelitian yang baik merupakan penelitian yang mampu memberikan nilai guna untuk menentukan prioritas keputusan. Setelah dilakukan penelitian didapatkan data yang akan diolah ke dalam metode AHP. Data diolah menggunakan tahapan sesuai dengan alur perhitungan. Berikut adalah tahapan yang akan dibuat pada penelitian ini, dapat dilihat pada Gambar 1.

dilakukan oleh Zulfi Azhar (2020) meneliti tentang

Jurnal Sistim Informasi dan Teknologi Vol. 3 No. 0.1 (2021) 7-12 


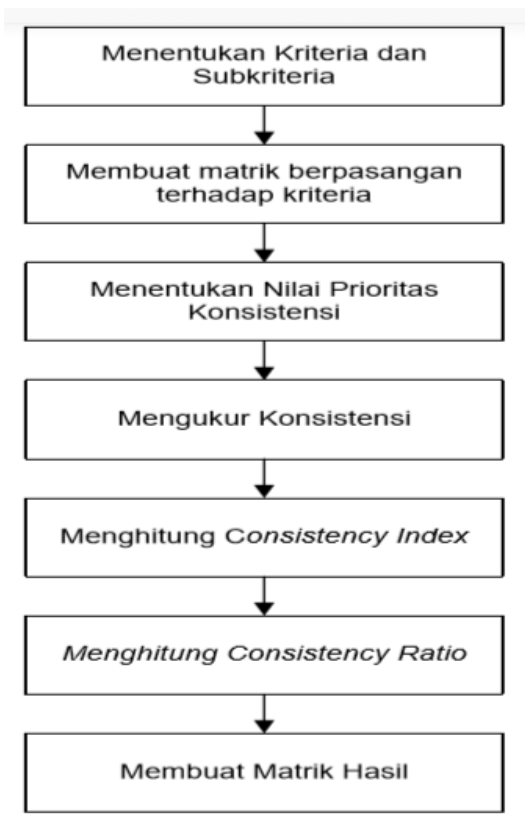

Gambar 1. Kerangka Penelitian kepentingan dengan skala 1 berarti kedua elemen sama pentingnya. Kepentingan dengan skala 3 berarti satu elemen sedikit lebih penting dari elemen lainnya.Kepentingan dengan skala 5 berarti satu elemen lebih penting dari elemen lainnya.Kepentingan skala 7 berarti jelas lebih mutlak penting dari elemen lainnya.Kepentingan skala 9 berarti satu elemen mutlak lebih penting dari elemen lainnya.Sedangkan kepentingan skala 2,4,6,8 itu berarti nilai antara dua memiliki pertimbangan nilai yang berdekatan.Kebalikkan untuk aktivitas o mendapatkan satu angka dibandingkan dengan aktivitas $\mathrm{p}$, maka $\mathrm{p}$ mempunyai nilai kebalikan dengan 0 .

\subsection{Nilai Prioritas}

Nilai-nilai perbandingan yang berhubungan dari keseluruhan alternatif terhadap kriteria.Nilai prioritas bisa sesuai dengan pertimbangan yang telah ditentukan untuk menghasilkan bobot dan prioritas.Prioritas ditentukan dari pandangan pihak peneliti atau para pakar yang kompeten terhadap pengambilan keputusan.

Beberapa tahapan penelitian dalam identifikasi motif songket Silungkang yang tepat menggunakan metode AHP.

\subsection{Kriteria dan Subkriteria}

Tahapan pertama menentukan elemen dari kriteria yang didapat saat melakukan penelitian. Dalam penelitian ini digunakan data motif dengan 3 kriteria, 4 subkriteria dan 13 data sampel motif songket Silungkang sebagai alternatif. Struktur hirarki menjelaskan bahwa untuk mendapatkan goal atau tujuan dari data diperlukan data kriteria dan subkriteria.Seperti yang dapat dilihat di struktur hirarki pengujian pada Gambar 2.

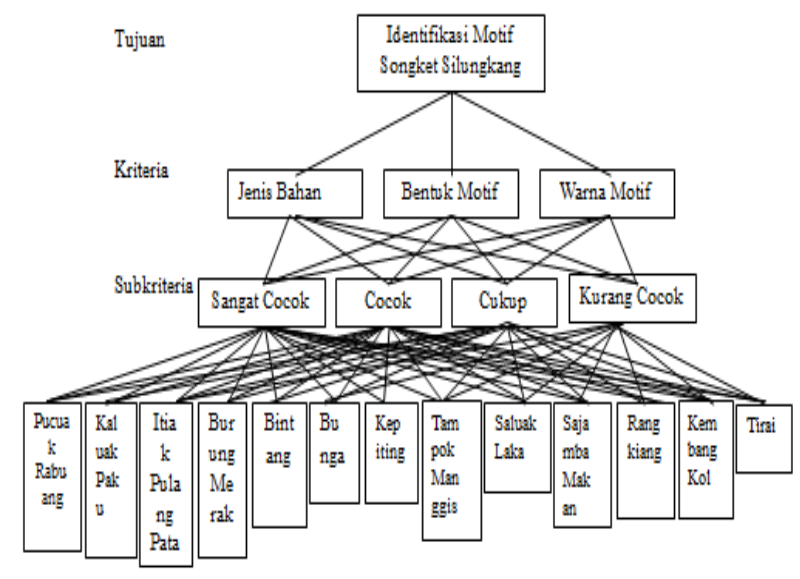

Gambar 2. Struktur Identifikasi Motif

\subsection{Matriks Berpasangan Kriteria}

Kriteria dan subkriteria yang telah ditentukan akan dilakukan dengan perbandingan berpasangan untuk berbagai masalah, skala 1 sampai 9 yaitu skala terbaik untuk menunjukkan pendapat tersebut. Dimana ukuran

\subsection{Ukur Konsistensi}

Ukur prioritas konsistensi penting dalam pengambilan keputusan untuk mengetahui seberapa penting keputusan dapat digunakan. Hal-hal yang dilakukan dalam langkah ini adalah sebagai berikut:

a. Mengalikan setiap nilai pada kolom pertama dengan prioritas elemen pertama, nilai pada kolom kedua dengan prioritas elemen kedua begitu selanjutnya sampai menemukan nilai prioritas.

b. Hitung nilai pada baris lalu jumlahkan.

c. Hasil dari penjumlahan baris dibagi dengan elemen prioritas yang berkaitan.

d. Lalu jumlahkan hasil bagi di atas dengan banyaknya elemen yang ada, hasilnya disebut $\lambda$ maks.

\subsection{Hitung Konsistensi Indeks (IK)}

Konsistensi Indeks dihitung untuk memastikan skala konsistensi berdasarkan tingkat pengambilan keputusan saat mengisi nilai pembanding antara sepasang elemen. Lakukan perhitungan berdasarkan rumus berikut:

$$
I K=\frac{(\lambda m a k s-s)}{(s-1)}
$$

Dimana s adalah jumlah elemen

\subsection{Hitung Konsistensi Rasio (RK)}

Konsistensi Rasio dihitung untuk menemukan hasil perbandingan antara indeks konsistensi dengan random indeks. Jika hasil rasio konsistensi kecil sama dengan 0,10 atau $10 \%$ berarti hasil pengguna dapat diterima. Lakukan perhitungan berdasarkan rumus berikut: 


$$
R K=\frac{I K}{R I}
$$

Dimana:

RK = Konsistensi Rasio;

IK = Konsistensi Indeks;

$\mathrm{RI}=$ Indeks Random.

\subsection{Matriks Hasil}

Setelah dilakukan analisa metode dengan perhitungan kriteria dan subkriteria, selanjutnya hasil perhitungan dimasukkan ke dalam matriks hasil yang akan menjadi acuan untuk menentukan nilai alternatif.

\section{Hasil dan Pembahasan}

Hasil yang dilakukan dalam identifikasi motif songket Silungkang dapat dilakukan perhitungan dengan metode AHP yang memiliki beberapa tahapan sebagai berikut:

\subsection{Kriteria dan Subkriteria}

Langkah pertama tentukan kriteria yang akan dilakukan perhitungan metode AHP, setelah data didapatkan. Kriteria yang dipertimbangkan pada penelitian ini terdiri dari tiga kriteria yaitu Jenis Bahan, Bentuk Motif dan Warna Motif.Dimana masing-masing kriteria memiliki subkriteria yang terdiri dari Sangat Cocok, Cocok, Cukup dan Kurang Cocok.

\subsection{Matriks BerpasanganKriteria}

Dimana pada tabel angka 1/1 dapat ditempatkan secara diagonal pada pojok kiri atas sampai dengan pojok kanan bawah, untuk menandakan bahwa perbandingan terhadap dua hal yang sama adalah 1 atau equal preferred. Matriks Perbandingan dari kriteria dapat dilihat pada Tabel 1.

Tabel 1. Matriks Perbandingan Kriteria

\begin{tabular}{cccc}
\hline & $\begin{array}{c}\text { Jenis } \\
\text { Bahan }\end{array}$ & $\begin{array}{c}\text { Bentuk } \\
\text { Motif }\end{array}$ & Warna Motif \\
\hline Jenis Bahan & $1 / 1$ & $3 / 1$ & $5 / 1$ \\
Bentuk Motif & $1 / 3$ & $1 / 1$ & $2 / 1$ \\
Warna Motif & $1 / 5$ & $1 / 2$ & $1 / 1$ \\
\hline
\end{tabular}

Matriks perbandingan kriteria menjelaskan perbandingan 1 kriteria dengan kriteria lain, dengan mengutamakan kriteria yang lebih penting. Seperti data pada Tabel 1 Jenis Bahan sedikit lebih penting jika dibandingkan dengan Bentuk Motif sehingga tingkat kepentingan 3/1. Jenis Bahan lebih penting jika dibandingkan dengan Warna Motif sehingga tingkat kepentingan 5/1.Bentuk Motif terdapat keraguan penilaian terhadap Warna Motif sehingga tingkat kepentingan $2 / 1$.Sedangkan $1 / 3,1 / 5$, dan $1 / 2$ pada Tabel 4.3 merupakan nilai kebalikan dari setiap kriteria.Sesuai dengan pertimbangan skala kepentingan yang dihitung untuk membandingkan nilai antar kriteria maupun subkriteria. Berikut ini adalah matriks berpasangan kriteria yang disajikan pada Tabel 2 .
Tabel 2.Matriks Berpasangan Kriteria

\begin{tabular}{cccc}
\hline \multicolumn{1}{c}{ Kriteria } & $\begin{array}{c}\text { Jenis } \\
\text { Bahan }\end{array}$ & $\begin{array}{c}\text { Bentuk } \\
\text { Motif }\end{array}$ & $\begin{array}{c}\text { Warna } \\
\text { Motif }\end{array}$ \\
\hline Jenis Bahan & 1,000 & 3,000 & 5,000 \\
Bentuk Motif & 0,333 & 1,000 & 2,000 \\
Warna Motif & 0,200 & 0,500 & 1,000 \\
\hline Jumlah & 1,533 & 4,500 & 8,000 \\
\hline
\end{tabular}

Dimana pada tabel angka 1,000 dapat ditempatkan secara diagonal pada pojok kiri atas sampai dengan pojok kanan bawah, untuk menandakan bahwa perbandingan terhadap dua hal yang sama adalah 1 atau equal preferred. Pada Jenis Bahan sedikit lebih penting jika dibandingkan dengan Bentuk Motif sehingga tingkat kepentingan 3,000.Jenis Bahan lebih penting jika dibandingkan dengan Warna Motif sehingga tingkat kepentingan 5,000.Bentuk Motif terdapat keraguan penilaian terhadap Warna Motif sehingga tingkat kepentingan 2,000.Sedangkan angka 0,333, 0,200 dan 0,500 merupakan nilai kebalikan dari setiap kriteria.

\subsection{Nilai Prioritas}

Matriks ini diperoleh dengan rumus berikut:

Nilai baris tiap kolom matriks perbandingan berpasangan dibagi dengan Jumlah masing-masing kolom. Sedangkan Nilai prioritas diperoleh dari nilai pada jumlah dari matriks perbandingan berpasangan dibagi dengan jumlah kriteria, dalam hal ini ada 3 kriteria.Dapat dilihat pada Tabel 3.

Tabel 3.Matriks Nilai Prioritas Kriteria

\begin{tabular}{cccccc}
\hline Kriteria & $\begin{array}{c}\text { Jenis } \\
\text { Bahan }\end{array}$ & $\begin{array}{c}\text { Bentuk } \\
\text { Motif }\end{array}$ & $\begin{array}{c}\text { Warna } \\
\text { Motif }\end{array}$ & Jumlah & Prioritas \\
\hline $\begin{array}{c}\text { Jenis } \\
\text { Bahan }\end{array}$ & 0,652 & 0,667 & 0,625 & 1,944 & 0,648 \\
$\begin{array}{c}\text { Bentuk } \\
\text { Motif }\end{array}$ & 0,217 & 0,222 & 0,250 & 0,689 & 0,230 \\
$\begin{array}{c}\text { Warna } \\
\text { Motif }\end{array}$ & 0,130 & 0,111 & 0,125 & 0,367 & 0,122 \\
\hline
\end{tabular}

Setelah dilakukan perbandingan matriks kemudian dilakukan pembobotan prioritas dari tiap kriteria.Hal ini dimaksudkan untuk memperoleh nilai prioritas dari tiap kriteria. Nilai 0,652 pada kolom Jenis Bahan pada Tabel 3 didapatkan dengan cara membagi kolom Jenis Bahan dengan kolom jumlah pada Tabel 2 dengan nilai $(1,000 / 1,533)$ sehingga didapatkan nilai hasilnya 0,652 dan begitu juga dengan kolom Bentuk Motif dan kolom Warna Motif. Pada kolom jumlah hasilnya juga didapatkan dengan menjumlahkan baris Jenis Bahan, Bentuk Motif dan Warna Motif dengan nilai $(0.652+0.667+0.625)$ hasilnya 1.944 begitu juga dengan baris Bentuk Motif dan baris Warna Motif. Nilai 0.648 pada baris Jenis Bahan didapatkan dari nilai jumlah dibagi dengan jumlah kriteria yaitu (1.944/3) dan begitu juga dengan baris Bentuk Motif dan Warna Motif. 
Putri Humairoh, Gunadi Widi Nurcahyo.

$\left.\begin{array}{l}0,648 \\ 0,230 \\ 0,122\end{array}\right) \quad\left(\begin{array}{lll}1,000 & 3,000 & 5,000 \\ 0,333 & 1,000 & 2,000 \\ 0,200 & 0,500 & 1,000\end{array}\right)$

Selanjutnya lakukan perkalian prioritas dengan matriks perbandingan kriteria, seperti yang dapat dilihat pada Tabel 4.

Tabel 4. Matriks Penjumlahan Tiap Baris

\begin{tabular}{lllll}
\hline Kriteria & $\begin{array}{l}\text { Jenis } \\
\text { Bahan }\end{array}$ & $\begin{array}{l}\text { Bentuk } \\
\text { Motif }\end{array}$ & $\begin{array}{l}\text { Warna } \\
\text { Motif }\end{array}$ & Jumlah \\
\hline Jenis Bahan & 0,648 & 0,689 & 0,611 & 1,948 \\
Bentuk Motif & 0,217 & 0,230 & 0,244 & 0,690 \\
Warna Motif & 0,130 & 0,115 & 0,122 & 0,367 \\
\hline
\end{tabular}

Nilai 0,648 pada baris Jenis Bahan kolom Jenis Bahan diperoleh dari prioritas matriks nilai kriteria dikalikan dengan setiap kolom Jenis Bahan sampai dengan baris Warna Motif $\quad(0,648 * 1,000=0,648)$ $(0,648 * 0,333=0,217)(0,648 * 0,200=0,130)$.Nilai 0,689 pada kolom Bentuk Motif baris Jenis Bahan diperoleh dari prioritas matriks nilai kriteria dikalikan dengan Oleh karena $\mathrm{RK}<0,1$, makakonsistensi rasiodari setiap kolom Bentuk Motif sampai dengan baris Warna perhitungan konsistensi kriteria dapat diterima.

Motif $\quad(0,230 * 3,000=0,689) \quad(0,230 * 1,000=0,230)$ $(0,230 * 0,500=0,115)$.Nilai 0,611 pada kolom Warna 3.7 Matriks Hasil

Motif baris Jenis Bahan diperoleh dari prioritas matriks nilai kriteria dikalikan dengan setiap kolom Warna Setelah dilakukan analisa menggunakan perhitungan Motif sampai dengan baris Warna Motif kriteria dan subkriteria, selanjutnya hasil perhitungan $(0,122 * 5,000=0,611) \quad(0,122 * 2,000=0,244)$ dimasukkan ke dalam matriks hasil prioritas. Hasil $(0,122 * 1,000=0,122)$. Kolom jumlah pada Tabel 3 prioritas dikelompokkan dengan elemen kriteria dan diperoleh dengan menjumlahkan nilai pada masing- subkriteria tersebut untuk menentukan bobot

masing baris Jenis Bahan (0,648 +0,689 hasil.Dapat disajikan dalam Tabel 6 .

$+0,611=1,948)$, pada baris Bentuk Motif didapatkan hasil $(0,217+0,230+0,244=0,690)$. Baris Warna Motif didapatkan hasil $(0,130+0,115+0,122=$ $0,367)$.

\subsection{Ukur Konsistensi}

Setelah matriks penjumlahan setiap baris didapatkan, selanjutnya ukur konsistensi rasio yang diperoleh dari hasil penjumlahan matriks penjumlahan setiap baris pada masing-masing kriteria atau subkriteria. Perhitungan tersebut ditambah dengan nilai prioritas setiap kriteria atau subkriteria pada matriks nilai. Dapat dilihat pada Tabel 5 .

Tabel 5.HitungKonsistensi Rasio

\begin{tabular}{lccc}
\hline & Jumlah Per Baris & Prioritas & Hasil \\
\hline Jenis & 1,948 & 0,648 & 2,596 \\
$\begin{array}{l}\text { Bahan } \\
\text { Bentuk } \\
\text { Motif }\end{array}$ & 0,690 & 0,230 & 0,920 \\
$\begin{array}{l}\text { Warna } \\
\text { Motif }\end{array}$ & 0,367 & 0,122 & 0,489 \\
\hline Jumlah & & & 4,005 \\
\hline
\end{tabular}

Dari Tabel 5diperoleh nilai-nilai sebagai berikut: Jumlah nilai hasil $=4,005$
Jumlah elemen $(\mathrm{s})=3$

$\lambda$ maks $=$ jumlah $/ \mathrm{s}=4,005 / 3=1,335$

\subsection{Hitung Konsistensi Indeks}

Setelah mendapatkan nilai $\lambda$ maks dari kriteria dan masing-masing subkriteria, langkah selanjutnya adalah mencari nilai Konsistensi Indeks (IK) dari kriteria.

$$
\begin{aligned}
\mathrm{IK} & =((\lambda \text { maks }-\mathrm{s}) /(\mathrm{s}-1)) \\
& =((1,335-3) /(3-1)) \\
& =-1,665 / 2=-0,832
\end{aligned}
$$

\subsection{Hitung Konsistensi Rasio}

Setelah didapatkan hasil konsistensi indeks, selanjutnya lakukan perhitungan konsistensi rasio untuk memastikan bahwa nilai konsistensi rasio $(\mathrm{RK})<=0,1$. Jika nilai rasio lebih besar dari 0,1 , maka matriks perbandingan harus diperbaiki. Berikut adalah perhitungan konsistensi rasio dari kriteria.

$$
\begin{aligned}
K & =\mathrm{IK} / \mathrm{RI} \\
& =-0,832 / 0,58 \\
& =-1,435
\end{aligned}
$$

Tabel 6.Matriks Hasil Prioritas

\begin{tabular}{ccc}
\hline Jenis Bahan & Bentuk Motif & Warna Motif \\
\hline 0.648 & 0.230 & 0.122 \\
Sangat Cocok & Sangat Cocok & Sangat Cocok \\
1,000 & 1,000 & 1,000 \\
Cocok & Cocok & Cocok \\
0.707 & 0.563 & 0.710 \\
Cukup & Cukup & Cukup \\
0.397 & 0.326 & 0.334 \\
Kurang Cocok & Kurang Cocok & Kurang Cocok \\
0.227 & 0.183 & 0.149 \\
\hline
\end{tabular}

Nilai 0.648 pada kolom Jenis Bahan, 0.230 pada kolom Bentuk Motif, 0.122 pada kolom Warna Motif didapatkan dari hasil matriks nilai kriteria pada Tabel 3Seandainya diberikan data motif songket Silungkang dengan kriteria jenis bahan dan subkriteria sangat cocok maka dikalikan $(0,648 \times 1,000=0,648)$, kriteria bentuk motif dengan subkriteria cocok maka juga dikalikan $(0,230 x 0,563=0,130)$, begitu juga seterusnya. Hasil akhir perhitungan perkalian matriks prioritas, dapat dilihat pada matriks hasil bobot pada Tabel 7 .

Jurnal Sistim Informasi dan Teknologi Vol. 3 No. 0.1 (2021) 7-12 
Tabel 7. Matriks Hasil Bobot

\begin{tabular}{|c|c|c|c|c|c|}
\hline No. & Alt & $\begin{array}{c}\text { Jenis } \\
\text { Bahan }\end{array}$ & $\begin{array}{c}\text { Bentuk } \\
\text { Motif }\end{array}$ & $\begin{array}{l}\text { Warna } \\
\text { Motif }\end{array}$ & Tot \\
\hline 1 & $\begin{array}{l}\text { Pucuak } \\
\text { Rabuang }\end{array}$ & 0,648 & 0,130 & 0,122 & 0,900 \\
\hline 2 & KaluakPaku & 0,648 & 0,130 & 0,041 & 0,819 \\
\hline 3 & $\begin{array}{l}\text { Itiak Pulang } \\
\text { Patang }\end{array}$ & 0,458 & 0,130 & 0,041 & 0,629 \\
\hline 4 & $\begin{array}{l}\text { Burung } \\
\text { Merak }\end{array}$ & 0,257 & 0,230 & 0,087 & 0,574 \\
\hline 5 & Bintang & 0,458 & 0,230 & 0,041 & 0,729 \\
\hline 6 & Bunga & 0,147 & 0,075 & 0,087 & 0,309 \\
\hline 7 & Kepiting & 0,257 & 0,129 & 0,087 & 0,473 \\
\hline 8 & $\begin{array}{l}\text { Tampok } \\
\text { Manggis }\end{array}$ & 0,147 & 0,129 & 0,041 & 0,317 \\
\hline 9 & $\begin{array}{l}\text { Saluak } \\
\text { Laka }\end{array}$ & 0,458 & 0,042 & 0,041 & 0,541 \\
\hline 10 & $\begin{array}{l}\text { Sajamba } \\
\text { Makan }\end{array}$ & 0,257 & 0,042 & 0,087 & 0,386 \\
\hline 11 & Rangkiang & 0,648 & 0,075 & 0,087 & 0,810 \\
\hline 12 & $\begin{array}{l}\text { Kembang } \\
\text { Kol }\end{array}$ & 0,458 & 0,129 & 0,122 & 0,709 \\
\hline 13 & Tirai & 0,458 & 0,075 & 0,087 & 0,620 \\
\hline
\end{tabular}

Nilai 0,648 pada kolom Jenis Bahan baris Motif Pucuak Rabuang pada Tabel 7, diperoleh dari nilai Motif Pucuak Rabuang untuk Jenis Bahan, yaitu Sangat Cocok dengan prioritas 1,000 dikalikan dengan prioritas Jenis Bahan sebesar 0,648 Tabel 6Kolom total pada Tabel 6 diperoleh dari penjumlahan pada masingmasing barisnya $(0,648+0,130+0,122=0,900)$. Total tertinggi akan diurutkan sesuai dengan nilai terbesar. Dapat dilihat dari data motif pucuak rabuang dengan nilai 0,900 . Nilai total inilah yang dipakai sebagai dasar untuk menetapkan dalam identifikasi Motif Songket Silungkang yang akan disetujui.

\section{Kesimpulan}

Penelitian ini menghasilkan matriks bobot hasil, dengan memperoleh nilai tertinggi yaitu $90 \%$. Sehingga dari hasil akhir perhitungan dapat diidentifikasi motif songket silungkang yang terpopuler di Toko Songket INJ yaitu motif Pucuak Rabuang. Hal ini akan sangat berguna bagi para peminat untuk memudahkan pengambilan keputusan yang terkait dengan identifikasi motif songket dalam memilih motif terbagus dan terpopuler.

\section{Daftar Rujukan}

[1] Winarto, F., \& Magdalena, M. (2020). Pengaruh Kualitas Pelayanan, Desain Produk dan Lokasi Terhadap Keputusan Pembelian Songket Silungkang Ande Darama Di Gunung Pangilun Kota Padang (Plaza Mabel Central Jepara). OSFPREPRINTS. DOI: https://doi.org/10.31219/osf.io/67yzv .

[2] Jung, D., Tuan, V. T., Tran, D. Q., Park, M., \& Park, S. (2020). Conceptual Framework of an Intelligent Decision Support System For Smart City Disaster Management. Applied Sciences, 10(2), 666. DOI: https://doi.org/10.3390/app10020666

[3] Noviyanti, T. (2019). Sistem Penunjang Keputusan Dalam Penerimaan Beasiswa PPA Menggunakan Metode Analytic Hierarchy Process (AHP) (Studi Kasus: Universitas Gunadarma). Jurnal Ilmiah Teknologi dan Rekayasa, 24(1), 35-44. DOI: http://dx.doi.org/10.35760/tr.2019.v24i1.1932 .

[4] Martins, D., Assis, R., Coelho, R., \& Almeida, F. (2019). Decision Support System for Business Ideas Competitions. Journal of Information Systems Engineering \& Management, 4(3). DOI: https://doi.org/10.29333/jisem/5892 .
[5] Kurniawan, A., Astuti, I. F., \& Cahyadi, D. (2020). Pemilihan Pemasok Suplemen Fitnes dengan Metode AHP (Analytic Hierarchy Process) (Studi Kasus: Toko Suplemen Malik Fitnes). Informatika Mulawarman: Jurnal Ilmiah Ilmu Komputer, 15(1), 32-38.

[6] Muzakir, A., \& Ependi, U. (2019). Analysis of the Use of Cellular Operators Using the Analytic Hierarchy Process Method. Journal of Information Systems and Informatics, 1(1), 29-38. DOI: https://doi.org/10.33557/journalisi.v1i1.5 .

[7] Corvin, J. A., Chan, I., Aguado Loi, C. X., Dollman, I., \& Gonzales, J. (2020). Analytic Hierarchy Process: An Innovative Technique For Culturally Tailoring Evidence-Based Interventions To Reduce Health Disparities. Health Expectations. DOI: https://doi.org/10.1111/hex.13022 .

[8] Azhar, Z. (2020). Penerapan Metode Analytical Hierarchy Process Dalam Pemilihan Bibit Jagung Unggul. JURTEKSI (Jurnal Teknologi dan Sistem Informasi), 6(2), 145-154.

[9] Leccese, F., Salvadori, G., Rocca, M., Buratti, C., \& Belloni, E. (2020). A Method to Assess Lighting Quality in Educational Rooms Using Analytic Hierarchy Process. Building And Environment, 168. https://doi.org/10.1016/j.buildenv.2019.106501 .

[10]Rosiska, E., \& Harman, R. (2019). Metode Analitical Hierarchy Process (AHP) dalam Pemilihan Umum Presiden Indonesia 2019. InfoTekJar: Jurnal Nasional Informatika dan Teknologi Jaringan, 3(2), 193-202. DOI: https://doi.org/10.30743/infotekjar.v3i2.1067 .

[11] Vojtek, M., \& Vojteková, J. (2019). Flood Susceptibility Mapping On a National Scale In Slovakia Using The Analytical Hierarchy Process. Water, 11(2), 364. DOI: https://doi.org/10.3390/w11020364.

[12]Hasni, S., Nurcahyo, G. W., \& Yunus, Y. (2019). Penetapan Penerimaan Besaran Pembiayaan pada KPN Syariah dengan Metode AHP. Jurnal Informasi dan Teknologi, 1(4), 18-23. DOI: https://doi.org/10.37034/jidt.v1i4.7 .

[13]Prasetyo, E. D. W., Handajani, M., \& Ismiyati. (2019). Criteria Analysis, Weight and Priority For Handling Bridges In Kudus District Using AHP and Promethee II Methods. Journal of Physics: Conference Series. DOI: http://doi.org/10.1088/17426596/1167/1/012009.

[14]Asti, G. K., \& Ekantari, N. (2020). Consumer Preferences For Dark Chocolate Products Fortified With Spirulina Platensis Using Analytical Hierarchy Process Method. E3S Web Of $\begin{array}{lll}\text { Conferences, } & 147 . & \text { DOI: }\end{array}$ http://dx.doi.org/10.1051/e3sconf/202014703021 .

[15] Siswanti, S., Wrehatnala, F. L., \& Kusumaningrum, A. (2020). Penerapan Metode Analytical Hierarchy Process dan Technique For Order Preference By Similarity To Ideal Solution Sebagai Pendukung Keputusan dalam Menentukan Kenaikan Jabatan Bagi Guru. Jurnal Ilmiah Sinus, 18(1), 35-48. DOI: http://dx.doi.org/10.30646/sinus.v18i1.438 .

[16]Darko, A., Chan, A. P. C., Ameyaw, E. E., Owusu, E. K., Pärn, E., \& Edwards, D. J. (2019). Review Of Application Of Analytic Hierarchy Process (AHP) In Construction. International Journal of Construction Management, 19(5), 436-452. DOI: https://doi.org/10.1080/15623599.2018.1452098 . 